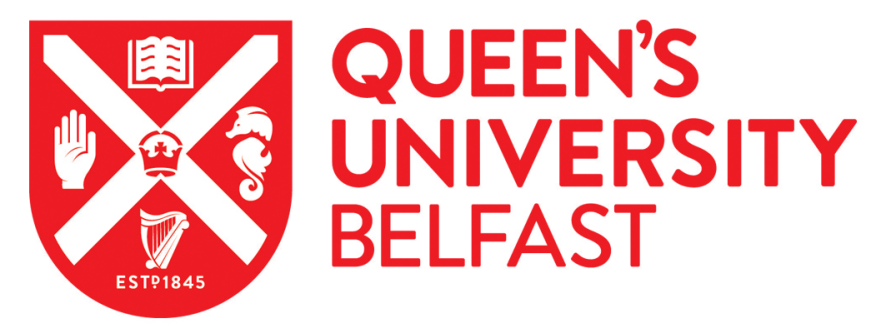

\title{
Feasibility of the use of poultry waste as polymer additives and implications for energy, cost and carbon
}

\author{
McGauran, T., Smyth, B., Dunne, N., \& Cunningham, E. (2021). Feasibility of the use of poultry waste as \\ polymer additives and implications for energy, cost and carbon. Journal of Cleaner Production, 291(125948), \\ [125948]. https://doi.org/10.1016/j.jclepro.2021.125948
}

Published in:

Journal of Cleaner Production

\section{Document Version:}

Peer reviewed version

Queen's University Belfast - Research Portal:

Link to publication record in Queen's University Belfast Research Portal

\section{Publisher rights}

Copyright 2021 Elsevier.

This manuscript is distributed under a Creative Commons Attribution-NonCommercial-NoDerivs License

(https://creativecommons.org/licenses/by-nc-nd/4.0/), which permits distribution and reproduction for non-commercial purposes, provided the author and source are cited.

\section{General rights}

Copyright for the publications made accessible via the Queen's University Belfast Research Portal is retained by the author(s) and / or other copyright owners and it is a condition of accessing these publications that users recognise and abide by the legal requirements associated with these rights.

\section{Take down policy}

The Research Portal is Queen's institutional repository that provides access to Queen's research output. Every effort has been made to ensure that content in the Research Portal does not infringe any person's rights, or applicable UK laws. If you discover content in the Research Portal that you believe breaches copyright or violates any law, please contact openaccess@qub.ac.uk. 


\title{
Feasibility of the Use of Poultry Waste as Polymer Additives and Implications for Energy, Cost and Carbon
}

\author{
Thomas McGauran ${ }^{1}$, Nicholas Dunne ${ }^{2}$, Beatrice M. Smyth ${ }^{1}$, Eoin Cunningham ${ }^{1}$ \\ Corresponding author: e.cunningham@qub.ac.uk \\ 1 School of Mechanical \& Aerospace Engineering, Queen's University Belfast, N. Ireland; \\ 2 School of Mechanical \& Manufacturing Engineering, Dublin City University, Ireland
}

\begin{abstract}
Increased poultry production worldwide has led to higher generation of poultry waste materials. To date, these materials have limited uses and often end up in landfill. Research has begun to investigate new applications for these waste materials, particularly as fillers and functional additives with a range of polymers. With oil supplies diminishing, use of an otherwise waste material to mitigate depletion rates represents a solution that will positively impact two global industries. This paper presents a technoeconomic analysis to determine the feasibility of using three abundant poultry waste materials, bone, meal and feathers, within the polymer industry, quantifying the energy, cost and carbon implications compared to conventional polymers and the potential oil savings compared to use as a bioenergy resource. Given the complexity of such an approach the assumptions involved have been detailed. Concurrently, compositional analysis yielded a detailed breakdown of each material (minerals and organic content), which was used to determine their potential as fillers in polymer processing. Calculations concluded that use as a polymer filler, in loadings up to $40 \% \mathrm{wt}$. for bone and meal and $60 \% \mathrm{wt}$. for feathers, provided high energy, carbon and cost savings to both the polymer and poultry industries. Crude oil savings were 5 times higher than use as a bioenergy source, showing the potential of poultry waste streams as polymer additives.
\end{abstract}

Keywords: Poultry, Waste, Energy, Polymer, Valorisation

\section{Introduction}

Increasing population, greater purchasing power and urbanization continue to drive increases in global poultry production. In 2018, the FAO (Food and Agriculture Organization) estimated global chicken meat production at $\sim 124$ million tonnes annually, contributing to $36.9 \%$ global meat production (Food and Agriculture Organization of the United Nations, 2019). Increased production has brought with it an increase in the volume of waste including litter, feathers, eggshell, carcass, blood, and wastewater. Currently 66 billion chickens 
(Compassion in World Farming, 2018), weighing 134 million tonnes are processed worldwide each year. Globally this results in 68 billion tonnes of waste per year, equivalent to the total annual domestic waste of 150 million people (Eurostat, 2015).

With this abundance of waste being generated, it must be ensured that these waste streams are sustainably managed. Nitrogen, phosphorous, heavy metals (particularly copper and zinc) and pathogenic microorganisms contained in the waste are of primary concern (Williams et al., 1999).

In the UK $\sim 1.1$ billion birds (including 1.05 billion broiler birds and 59 million boiling fowl) are slaughtered annually (Department for Environment Food \& Rural Affairs, 2020), each with an average mass of around $2.2 \mathrm{~kg}$ (Bain et al., 2018). These yield over 1 billion tonnes of bone, feather, offal, and blood (Table 1).

Table 1. Breakdown of a chickens primary components - Dry weight breakdown (UK).

\begin{tabular}{cccc}
\hline Material & \% of bird & kg per bird & \% dry matter \\
\hline Offal & 23.7 & 0.521 & 34.7 \\
Bone & 18.4 & 0.405 & 90.1 \\
Feather & 5.5 & 0.121 & 27.6 \\
Eggshell & -- & 0.005 & 99.2 \\
Blood & 2.4 & 0.053 & 19.1 \\
\hline
\end{tabular}

The poultry sector is also an emitter of greenhouse gas (GHG) emissions. Agriculture accounted for $9.9 \%$ of EU GHG emissions in 2014 (Eurostat, 2018), with poultry farming responsible for $8-9 \%$ of agricultural emissions (Leip et al., 2010). Research suggests that energy-related $\mathrm{CO}_{2}$ emissions are responsible for up to $30 \%$ of $\mathrm{GHG}$ emissions from poultry agriculture (Leip et al., 2010), and, of the energy embedded in the poultry production chain (agriculture, processing, packaging, consumption and end-of-life), almost 90\% is from fossil sources (Monforti-Ferrario et al., 2015). While the GHG emissions associated with poultry agriculture are lower than those for ruminant and pig production (for total emissions and emissions per $\mathrm{kg}$ of product) (Leip et al., 2010), the trend for increased poultry consumption (Bolan et al., 2010) indicates that the associated share of emissions is likely to rise.

Increased consumption, coupled with: 1) increasingly stringent agri-environmental legislation targeting reduced GHG emissions and increased uptake of renewable energy and 2) waste-to-energy incentivization schemes, have led the poultry sector toward the implementation of anerobic digestion (biogas production) (Ma et al., 2019), direct combustion (heat/power generation) (Kantarli et al., 2016), and gasification (syngas production) (Stingone and Wing, 2011). The EU has set targets for a $20 \%$ renewable energy 
share of gross domestic energy consumption by 2020 (European Parliament, 2009a) and 20\% reduction in GHG emissions on 1990 levels by the same year (European Parliament, 2009b). Such targets are supported in the agricultural sector by the EU's Rural Development Policy. However, waste-to-energy is not the only option for agri-waste valorization and fossil fuel displacement. Legislation and societal pressures have urged changes to pathways further up the waste hierarchy pyramid outlined in Directive 2008/98/EC (European Parliament, 2008). While energy recovery and disposal (landfill) are the least desirable (lowest tier) end of life pathways, reuse and recycling (i.e. the use of waste materials for secondary uses, possibly replacing virgin materials) are options further up the hierarchy and offer more desirable middle tier solutions (Quina et al., 2017).

\subsection{Poultry waste as polymer substitute}

Poultry wastes streams are currently reused as compost, fertilizer and pet food (Jayathilakan et al., 2012). Evidence in literature also suggests that poultry waste materials could be used for polymer production, but there has been limited research to date. This idea is not without merit: waste streams including agricultural and forestry (Treinyte et al., 2018), used tyres (Sienkiewicz et al., 2017), palm leaves (Binhussain and El-Tonsy, 2013) and plantbased materials (Shogren et al., 2019) have all be used as polymer filler in loadings up to $50 \%$ wt. Biomass or ash produced via processes such as incineration have been also used for as polymer additives (Igarza et al., 2014). Such use displaces petroleum-based polymers (plastics) with a sustainable resource. A key driver for this has been increasing global dependence on plastic culminating in levels of polymer production in the first decade of the twenty-first century exceeding that from the previous 100 years combined (Thompson et al., 2009). The move for bio-based polymers by these environmental concerns and those in society (Scherer et al., 2017), with the use of waste materials highlighted as one method to achieved this (Ng and Sadhukhan, 2017).

Poultry wastes, or their constituent elements/compounds have huge potential to be utilized as polymer fillers or functional additives. However, composition varies with different production practices and across different geographical locations (Medugu et al., 2010). Characterisation is needed to gain accurate compositional breakdown for broiler chickens produced according to typical EU production practices. Their potential as an additive then depends on several factors: chemistry, ability to retrieve, particle size and morphology (Xanthos, 2010).

To date, the use of poultry waste streams as polymer additives has been limited to eggshell (McGauran et al., 2020), blood (Piazza et al., 2011) and feathers (Reddy, 2015). 
Eggshell is the most commonly used having been incorporated into polymers in loading up to $40 \%$ wt. to provide better improvements in tensile properties (McGauran et al., 2020). However poultry waste streams such as bone, meal and feathers are available in much higher quantities (Table 1), yet have not been investigated to similar levels.

To date, there has been no research on the use of poultry bones (or a derived powder) in polymers. Research has, however, developed composites incorporating $5-15 \%$ wt. bovine bone with polypropylene (Asuke et al., 2012), where increases in tensile and flexural properties were observed. Likewise hydroxyapatite (the predominant mineral found in bone) is regularly used as a functional additive in polymers utilized in biomedical applications. Research has demonstrated the potential for successful integration of bone particulates (or its facsimiles) into a range of polymer matrices (Xanthos, 2010). The use of poultry meal for polymer applications has also not yet been investigated. While no previous work has looked exclusively at poultry meal, films have been produced using mixed-meat and bone meal (in loadings up to 60\%) blended with low-low density polyethylene (LLDPE) (Lukubira and Ogale, 2014). Due to the differences in protein structure between poultry meal and meat and bone meal, it is unknown whether this process could be recreated using poultry meal as the base material. Feather, utilized for fibre reinforcement, have been commonly used in a range of polymers (Reddy, 2015). The branched, fibrous nature of feathers were shown in literature to have good mechanical properties itself including tensile strength of $206 \mathrm{MPa}$, modulus of 3.6 GPa and elongation of 6.9\% (Zhan and Wool, 2011). Research found increases in tensile and flexural properties with feather loading over 50\% wt. (Reddy and Yang, 2010).

Ultimately the use of poultry wastes in polymer production would replace fossil oilbased feedstock, bring sustainability benefits, potentially both in terms of cost savings and displacement of fossil fuels. With $1.92 \mathrm{~kg}$ of crude oil needed (44\% as a feedstock, $56 \%$ for processing energy) on average to produce $1 \mathrm{~kg}$ of plastics (Hammond and Jones, 2011), the industry uses 6.9 billion barrels of oil per year, yielding $~ 359$ million tonnes of polymer (Plastics Europe, 2019). This paper focuses on the three most plentiful poultry wastes, bone, meal and feathers, and seeks to answer the following questions: 1) Are poultry wastes suitable for polymer production as fillers, functional additives or polymer precursors?, and 2) What are the energy, cost and carbon savings compared to conventional polymers and the oil savings compared to use as a bioenergy source? 


\section{Materials and Methods}

\subsection{Overview}

The aim of this paper was to investigate the suitability of poultry wastes (bone, meal and feathers) for polymer production, both in terms of material characterization and the energy, carbon and cost implications. The energy, cost and carbon impacts associated with biopolymer use were compared with those from conventional polymers, while the impact on resource utilization (i.e. oil feedstock) was also considered through a comparison of use of the wastes for biopolymers versus use as a bioenergy source.

The main steps (Figure 1) involved: Phase 1) compositional analysis of UK broiler followed by comparing the characteristics of retrieved components to traditional fillers and functional additives yielding potential value and oil displacement and Phase 2) calculating energy (and comparing to use as energy source), carbon and cost saving compared to a convectional plastic.

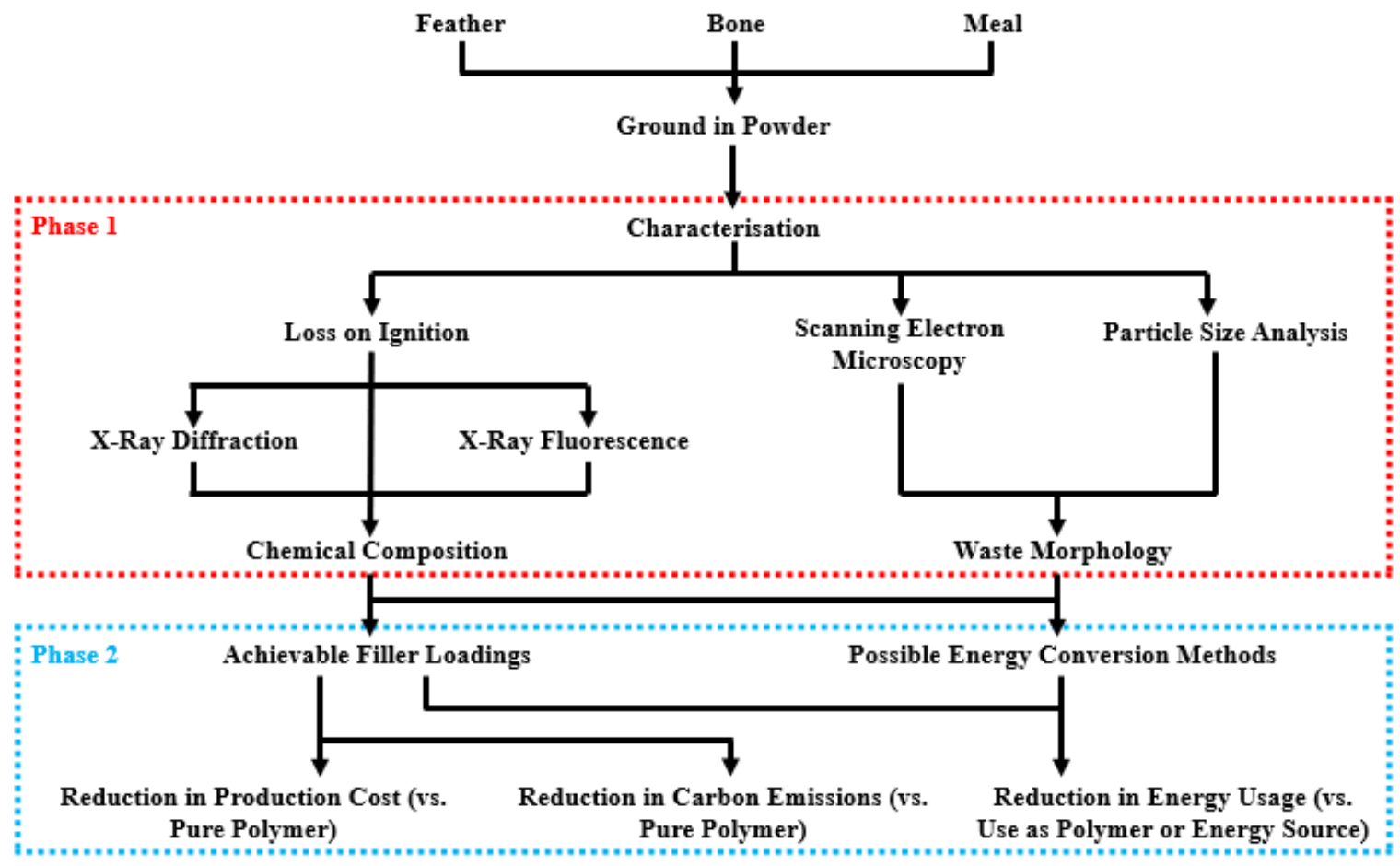

Figure 1 - Flow diagram of methodology broken into two distinct phases (Phase 1 - Compositional analysis,

Phase 2 - Energy, carbon and cost saving)

\subsection{Material Characterisation}

Poultry bone, meal and feathers were provided by poultry supplier Moy Park (Armagh, UK). Loss on ignition (LOI), $\mathrm{x}$-ray diffraction (XRD) and $\mathrm{x}$-ray fluorescence (XRF) provided quantification of composition coupled with particle size analysis and scanning electron 
microscopy (SEM) also being utilized. For each technique, a fine powder was required. Grinding was carried out using a pestle and mortar for both bone (with liquid nitrogen) and feather (dry). Poultry meal was already in powder form and was used as received.

Particle size analysis was carried out using a two laser Sympatec HELOS/BF Particle Sizer (Sympatec, Germany) with water used as a dispersant. Samples of $1 \mathrm{~g}$ of powder material were analysed to determine particle size distribution and a D50 value.

Loss on ignition testing was carried out using a standard procedure (Heiri et al., 2001) to determine moisture, organic, carbonate and inorganic content of samples. Samples of known mass were heated in an oven at temperatures of 105,450 and $950^{\circ} \mathrm{C}$ for 24,6 and 2 hours respectively. Samples were weighed after each heating regime with mass losses used to determine percentage moisture, organic, carbonate and inorganic content. The ashes produced were used for XRD and XRF analysis.

The composition of samples ( $3 \mathrm{~g}$ ) was determined using a Philips X-Pert Pro-MPD diffractometer (Philips, Netherlands). The x-ray tube rotated between 5 and $65^{\circ}$ in steps of $0.0167^{\circ}$. The results were compared to a structural database (X'Pert High Score and X'Pert Plus (V2.2)).

XRF quantifies the base elements present (in parts per million). Poultry samples weighing ( $3 \mathrm{~g}$ ), along with two known composition samples (used to off-set errors in results), were tested using a Hitachi X-Supreme 8000 XRF analyser (Hitachi, Japan). Results from XRF were presented in mineral oxide form and were converted using oxide-to-element conversion tables (Jepspectro.com, 2016) into raw material form, with values reported in parts per million (ppm).

XRD results showed individual compound forms. This information, along with elementto-compound (carbonate or oxide) conversion factors (Tibaland, 2019), was used to gain an accurate chemical composition of poultry waste materials (McLachlan and MacLeod, 1959).

SEM testing was carried out using a Jeol 6500 FEGSEM (Jeol, Japan) operating with an acceleration voltage of $3-5 \mathrm{kV}$. Images were taken at magnifications of between X250 and X10000. Samples, in powder form, were bonded to a SEM stubs, before sputter coating a 50 nm gold layer on top to improve image quality.

\subsection{Energy, Carbon and Cost Implications}

The first step was to investigate the energy, carbon and cost impacts of poultry-waste polymers compared to conventional polymers (Figure 2). The use of poultry wastes in place of conventional oil-based feedstocks has an impact on both the direct and indirect energy of 
the system. Direct energy is that used directly in the production process, e.g., the electricity used to power processing machinery, while indirect energy arises from non-energy items used in the production process, e.g., the energy used to produce the conventional polymer feedstock. The direct energy requirements for processing (and hence the associated costs and carbon emissions) are different for poultry waste feedstock than for oil-based feedstock, due to the different steps required. The energy and carbon arising from the production of poultry waste feedstock were assumed to be associated with the agricultural sector and therefore outside the boundary of the current analysis.

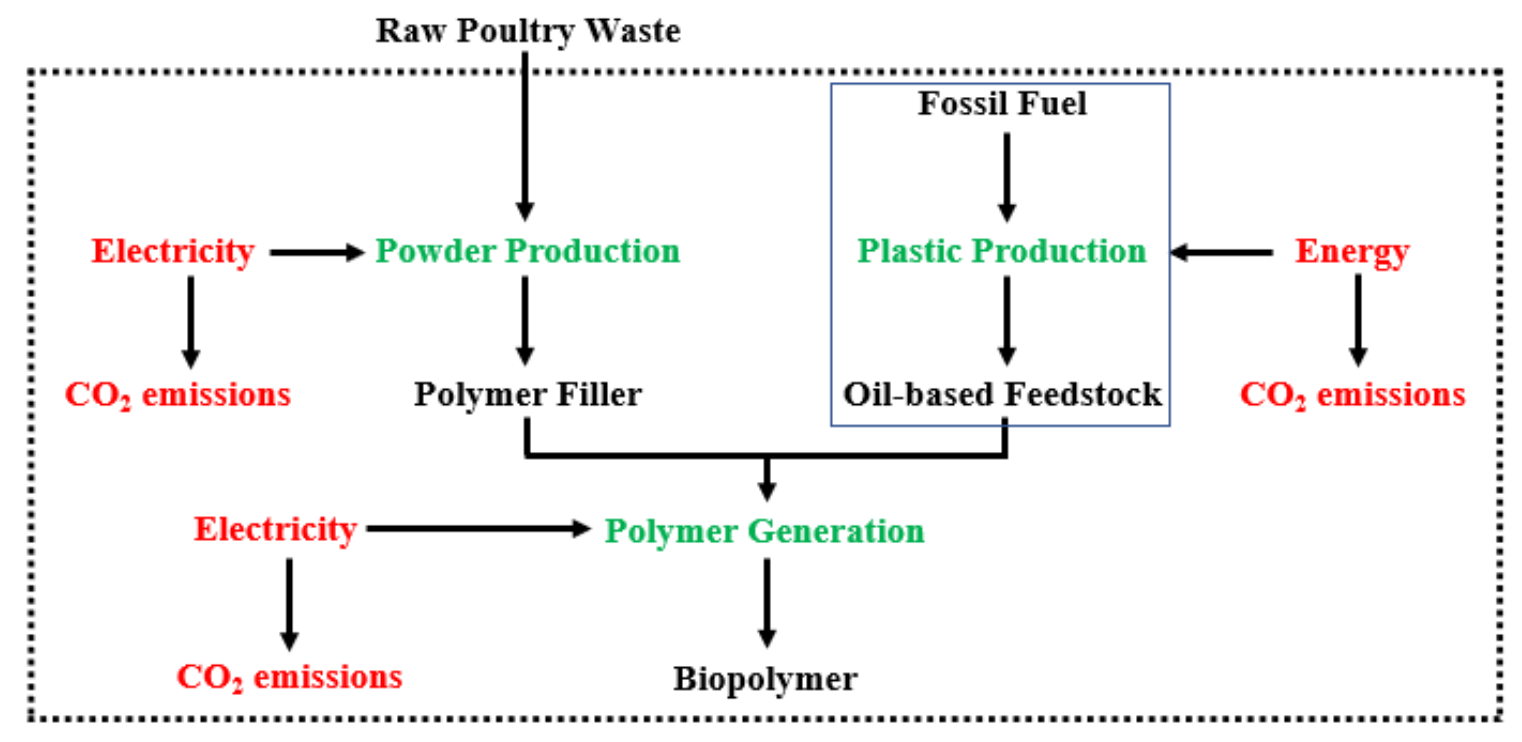

Figure 2 - Flowchart of biopolymer production process investigated showing production steps, points of energy input and carbon emissions (the dotted line indicates the boundary of the analysis, the red font is for energy and carbon flows, the black font for material flows, and the green font for production processes)

Three biopolymer mixes were investigated, with loadings of $40 \%$ wt. bone, $40 \%$ wt. meal, and $60 \%$ wt. feather, respectively, with raw polypropylene. These loadings were considered the maximum practically achievable and were determined from first considering chemical composition (from characterization), and then comparing the results to relevant procedures in the literature using similar materials at high loadings. Polypropylene was selected as the base polymer, as it is the most commonly used single polymer, particularly in food packaging and for short-life uses (Plastics Europe, 2019). Virgin polypropylene has an energy footprint of $95.9 \mathrm{MJ} / \mathrm{kg}$ (Hammond and Jones, 2011), a cost of $£ 1.20 / \mathrm{kg}$ (Plasteurope.com, 2019) and a carbon footprint of $3.96 \mathrm{kgCO}_{2} \mathrm{e} / \mathrm{kg}$ (Ashby, 2013). The embodied energy and carbon values reflect the direct and indirect energy consumed during production and the associated fuel and process carbon emissions. 
It was assumed that, when processed into a dry powder, the poultry waste streams could be incorporated directly into polymer processing as a high loading filler. Feathers and bone need to be cleaned, dried and milled prior to the mixing and extrusion processes, while meal requires only drying and milling. Machine running times and conditions, and the associated energy usage and costs, in order to $a$ ) transform raw poultry waste into a filler material and b) transform poultry waste filler and raw polymer mixture into a final material, were based on parameters used in literature and equipment specifications (further details in Appendix 1). The energy for processing (filler and polymer mixture generation) was assumed to be from wind-generated electricity (transmission and distribution losses were neglected). The cost of electricity was taken as $£ 0.221 / \mathrm{MJ}$ (Sustainable Energy Authority of Ireland, 2015) and the carbon footprint as $0.0018 \mathrm{kgCO}_{2} \mathrm{e} / \mathrm{MJ}\left(6.3 \mathrm{gCO}_{2} \mathrm{e} / \mathrm{kWh}\right.$ ) (Wang and Sun, 2012). A second scenario was also investigated with the use of grid electricity with emissions of 0.0648 $\mathrm{kgCO}_{2} \mathrm{e} / \mathrm{kWh}\left(233 \mathrm{gCO}_{2} \mathrm{e} / \mathrm{kWh}\right.$ ) (Department for Business. Energy \& Industrial Strategy, 2020).

Machinery payback was calculated using machinery capital, installation and maintenance costs over a period of 20 years (data in Appendix 1). Labour costs were excluded from the base case analysis due to the wide range of influencing variables including the number of personnel required, average wages (dependent on country/position) and operational hours. However, the potential impact of the inclusion of labour costs is investigated later in the paper in the discussion section. This was done by calculating how many workers could be employed using the savings generated for poultry addition for 1 month. The total cost of employing a technician in the UK (including insurance contribution and pension) is in the order of $£ 44,000$ (Queen’s University Belfast, 2020).

Daily poultry waste quantities were based on 1.1 billion birds slaughtered annually within the UK (Department for Environment Food \& Rural Affairs, 2020). Considering dry matter values, on average a chicken produces $0.339 \mathrm{~kg}$ of bone, $0.148 \mathrm{~kg}$ of meal (rendered from offal) and $0.031 \mathrm{~kg}$ of feathers. These values were used to estimate daily energy, carbon and cost impacts of biobased polymers produced from each of the three materials and compared to corresponding values for conventional polymers (Box 1). 
Box 1 - Calculation of daily energy, carbon and financial savings of biobased polymers from UK poultry wastes compared to conventional polymers

\begin{tabular}{ccc}
\hline Total savings & Equation & Assumptions $^{\mathbf{1}}$ \\
\hline Energy (E) & $E=\sum_{i=1}^{n=3} e_{i} m_{i}$ & $\begin{array}{l}\mathrm{e}_{\mathrm{i}}=\text { the energy saving per kg of waste used for material } \mathrm{i} . \\
\mathrm{c}_{\mathrm{i}}=\text { the carbon saving per kg of waste used for material } \mathrm{i} \\
\mathrm{f}_{\mathrm{i}}=\text { the cost saving per kg of waste used for material } \mathrm{i} \\
\mathrm{n}=\text { the number of materials (3: bone, meal and feathers) } \\
\text { Carbon (C) }\end{array}$ \\
\hline Financial (F) $\quad F=\sum_{i=1}^{n=3} c_{i} m_{i}$ the mass of material i per daily production \\
\hline
\end{tabular}

\footnotetext{
${ }^{1}$ The energy, cost and carbon required to process poultry-based polymers was subtracted from that associated with producing the conventional polymer. The energy value includes both the energy required for processing the polymer and that for producing the raw material. The carbon emissions for processing poultry-based polymers are related to the energy use, while those for the conventional polymer are related to both energy and process emissions. The estimated cost of the biopolymer excludes labour costs.
}

The next step in the analysis was to compare the oil saved through the displacement of fossil-based polymer feedstock with the potential oil savings if the poultry waste materials were used as a bioenergy source instead. The properties of each waste stream were used to select suitable energy conversion techniques. Fixed bed gasification can be used for feathers (Kwiatkowski et al., 2013), due to the high organics (volatile) content and subsequent low ash content. Traditionally, bone, along with meat-and-bone-meal (MBM) have been combusted for heat generation, however processes including gasification and pyrolysis can create higher value energy products including syngas or bio-oil. Both the combustion and pyrolysis routes were therefore considered. Poultry meal (as offal) is suited for anerobic digestion due to high moisture and low lignin content, but this route was not considered because of restrictions in the UK on handling and processing of offal.

The energy output from the combustion of bone and meal was estimated from (Phyllis2, 2017), while the energy arising from the pyrolysis of the same material to produce bio-oil was taken from (McGlashan, 2003). It was assumed that feathers are gasified to produce syngas, with gasifier losses of 3.9\% (Kwiatkowski et al., 2013). The quantity of oil displaced was calculated based on a boiler efficiency of $80 \%$. The quantity of oil required for conventional polymer production was assumed to be $2.29 \mathrm{~kg}$ per kilogram of polypropylene (Hammond and Jones, 2011). 


\section{Results and Discussion}

\subsection{Material Characterisation}

\subsubsection{Particle Size Analysis}

Particle size distribution for each waste stream ranged from a consistent powder for bone and meal to fibres of varying length for feathers. D50 values were recorded at 46.0, 44.0 and $218.2 \mu \mathrm{m}$ for bone, meal and feather fibres respectively.

\subsubsection{Loss on Ignition}

The mass of samples before and after each heating stage was recorded (Table 2). These values were used to calculate the percentage of moisture, organics, carbonate and inorganics present in each material using equations $1-4$ :

Table 2. Mass of samples throughout LOI procedure and calculated percentage moisture, organic, carbonate and inorganic content

\begin{tabular}{cccc|cccc}
\hline Temperature & Bone & Meal & Feather & $\%$ & Bone & Meal & Feather \\
\hline Initial mass $(\mathrm{g})$ & 21.61 & 73.62 & 5.85 & moisture & 9.8 & 5.6 & 8.5 \\
Mass at $\mathbf{1 0 5}^{\circ} \mathbf{C}(\mathrm{g})$ & 19.51 & 69.54 & 5.35 & organics & 44.0 & 58.6 & 71.8 \\
Mass at $\mathbf{4 5 0}^{\circ} \mathbf{C}(\mathrm{g})$ & 10.00 & 26.37 & 1.15 & carbonates & 13.7 & 11.2 & 7.9 \\
Mass at $\mathbf{9 5 0}^{\circ} \mathbf{C}(\mathbf{g})$ & 7.02 & 18.14 & 0.69 & inorganics & 32.5 & 24.6 & 11.8 \\
\hline
\end{tabular}

$$
\begin{array}{cc}
\% \text { moisture }=\frac{\text { mass }_{\text {initial }}-\text { mass }_{@ 105^{\circ} \mathrm{C}}}{\text { mass }_{\text {initial }}} \times 100 & \text { Equation 1 } \\
\% \text { organics }=\frac{\text { mass }_{@ 105^{\circ} \mathrm{C}}-\text { mass }_{@ 450^{\circ} \mathrm{C}}}{\text { mass }_{\text {initial }}} \times 100 & \text { Equation 2 } \\
\% \text { carbonates }=\frac{\text { mass }_{@ 450^{\circ} \mathrm{C}}-\text { mass }_{@ 950^{\circ} \mathrm{C}}}{\text { mass }_{\text {initial }}} \times 100 & \text { Equation 3 } \\
\% \text { inorganics }=\frac{\text { mass }_{@ 950^{\circ} \mathrm{C}}}{\text { mass }_{\text {initial }}} \times 100 & \text { Equation 4 }
\end{array}
$$

\subsubsection{X-Ray Diffraction}

XRD with the addition of Rietveld analysis was able to quantify the dominant mineral compounds present in each sample. For all three materials, compounds of calcium phosphate were the dominant minerals. Hydroxyapatite was the major compound in feathers, whitlockite in poultry meal and equal amount of both in poultry bones. Calcium sulphate was 
also present in large amounts in both poultry meal and feathers. Feathers also contained notable amounts of magnesium oxide and calcium carbonate.

\subsubsection{X-Ray Fluorescence}

XRF results provided an accurate review of the elemental composition of tested poultry waste samples (Table 3).

Table 3. XRF results for poultry waste streams showing all major elements present within poultry waste

\begin{tabular}{cccc}
\multicolumn{3}{c}{ streams } \\
\hline Bone (ppm) & Meal (ppm) & Feather (ppm) \\
\hline Phosphorus & 25,400 & 20,600 & 239,854 \\
Sulphur & 6220 & 11,500 & 76,648 \\
Magnesium & 3390 & 6850 & 72,708 \\
Silicon & 7510 & 1800 & 64,766 \\
Zinc & 300 & 368 & 19,258 \\
Sodium & 11,800 & 96 & 15,947 \\
Potassium & 7120 & 10,200 & 13,428 \\
Other & 6921 & 8890 & 8218 \\
\hline
\end{tabular}

The XRD and XRF results were combined to work out detailed chemical composition for each waste stream (Table 4). 
Table 4. Material composition of poultry waste samples (based on characterization data), with possible polymer properties improved when added as filler or functional additive

\begin{tabular}{|c|c|c|c|c|}
\hline \multirow{2}{*}{ Component } & Bone & Meal & Feather & \multirow{2}{*}{$\begin{array}{c}\text { Associated polymer property } \\
\text { improvement with incorporation }\end{array}$} \\
\hline & \multicolumn{3}{|c|}{$\%$ of total } & \\
\hline Moisture & 9.8 & 5.6 & 8.5 & - \\
\hline Organics & 44.0 & 58.6 & 73.2 & Bio-degradability (Davis and Song, 2006) \\
\hline Inorganics & 46.2 & 35.8 & 18.3 & See below \\
\hline \multicolumn{5}{|c|}{$\%$ of inorganics } \\
\hline Calcium phosphate & 69.9 & 82.8 & 39.6 & $\begin{array}{l}\text { Tensile strength, hardness, flexural } \\
\text { strength, flame retardant (Asuke et al., } \\
\text { 2012; Kantharia et al., 2014) }\end{array}$ \\
\hline Calcium carbonate & Trace & Trace & 7.3 & $\begin{array}{l}\text { Impact strength, Young's modulus (Toro et } \\
\text { al., 2007) }\end{array}$ \\
\hline Calcium sulphate & 7.5 & 10.4 & 28.0 & $\begin{array}{l}\text { Impact strength, Young's modulus } \\
\text { (Murariu et al., 2007) }\end{array}$ \\
\hline Magnesium oxide & Trace & 2.7 & 12.1 & $\begin{array}{l}\text { Flame retardant (Musselman and Greene, } \\
\qquad 1996)\end{array}$ \\
\hline Silicon oxide (quartz) & 5.2 & 0.6 & 3.6 & Tensile strenght (Zubov et al., 1967) \\
\hline Potassium bicarbonate & 4.9 & - & Trace & $\begin{array}{l}\text { Flame retardant (Musselman and Greene, } \\
\qquad 1996)\end{array}$ \\
\hline Zinc oxide & Trace & Trace & 3.0 & Tensile modulus (Chae and Kim, 2005) \\
\hline Sodium bicarbonate & 8.2 & Trace & 2.5 & $\begin{array}{l}\text { Increases ignition time (Casano and Piva, } \\
\qquad 2016)\end{array}$ \\
\hline Other & 4.3 & 3.5 & 3.9 & - \\
\hline
\end{tabular}

\subsection{Analysis of Poultry Waste Streams}

\subsubsection{Bone}

Of the three poultry waste materials tested, bone was the only one with substantial organic and inorganic content (Table 2). Its inorganic contents contained high amounts of calcium phosphate (hydroxyapatite and whitlockite). Compounds of sodium, silicon, potassium and sulphur were also detected in trace amounts. SEM images (Appendix 2) along with particle size data, showed that despite its toughness (with liquid nitrogen needed to breakdown the material), spherical particles (most desirable particle type (Xanthos, 2010)) of consistent size (D50 of $46.0 \mu \mathrm{m}$ ) were achieved via grinding (a desirable trait for polymer additives (Xanthos, 2010)).

The abundance of inorganic minerals in bone samples highlights potential use as a polymer filler or additive (Table 4). For instance, calcium phosphate is capable of increasing 
tensile and flexural strength (Asuke et al., 2012). One issue with current plastics materials is long degradation times (Dietrich et al., 2017). The addition of organic components can also enhance the bio-degradation profile. Under composting for example, hydrophobic synthetic polymers are resistant to biological attack from microorganisms. When buried (in landfilling) they may are denied photo-degradation via UV light exposure (Nayak, 1999). With the addition of bone, or other poultry waste streams, the presence of organics and other minerals can manipulate hydrophobicity levels facilitating accelerated polymer breakdown (Davis and Song, 2006). This provides added incentive for their incorporation and weight to continued investigation.

\subsubsection{Meal}

Poultry meal is predominantly comprised on organic materials (58.6\%, Table 2$)$ such as proteins and fats. Like bone, calcium phosphate was the most abundant inorganic mineral. Other minerals such as calcium sulphate (with traces of sodium), silicon oxide and magnesium oxide were also present. SEM micrographs (Appendix 2) for meal exhibited uniform spherical particles, with a D50 particle size of $44.0 \mu \mathrm{m}$. Aligning with particle size distributions typical for fillers, this, and it's composition warrant, point towards its potential (and warranted investigation) as a polymer additive (Xanthos, 2010). The smooth nature was likely due to the heating effect removing rough edges, as cited in literature (Bethanis et al., 2002).

The presence of high amounts of organic materials, once again, points toward potential applications as functional additive capable of influencing the bio-degradation profile of polymer (Davis and Song, 2006). As a polymer filler, the similarities in inorganic content to bone, mainly hydroxyapatite, suggest capability to work in a similar manner, although no previous research supports this. The hydrolysis process, used to produce meal, can, however, be altered to change the composition to more desirable values. Awonorin et al. showed that similar poultry samples produced meals of different protein, fat and ash contents with changes to processing times and temperatures (Awonorin et al., 1995), showing final composition can be altered, although a trial and error approach of the process may be need to adjust values to desirable levels.

\subsubsection{Feather}

Feathers consist of two different components of varying surface properties. The quill is a solid hard structure, while the barbs (fibres branching out from the quill) are soft, thin structures. SEM imaging (Appendix 2) showed feather barbs, consisting of long thin fibres 
(thickness of $\sim 50 \mu \mathrm{m}$ ), with thinner barbules (width $>10 \mu \mathrm{m}$ ) branching out. The ground feather fibres had a D50 value of $218.2 \mu \mathrm{m}$. Compositionally, organic matter (78\% dry weight) in the form of keratin (a natural polymer (Hood and Healy, 1994)) constitutes the main component of poultry feather. The inorganic portion is comprised mainly of calcium phosphate, calcium sulphate and calcium carbonate, along with magnesium oxide.

Keratin structures have been highlighted as a useful filler material by improving tensile and flexural properties with many polymers (Reddy, 2015) and have been used in quantities of up to $60 \%$ wt. (Reddy and Yang, 2010). The presence of calcium sulphate has also been cited as contributing to improvements in impact strength and Young's modulus, through improved interfacial bonding with base polymers including poly(lactic acid) (Murariu et al., 2007). As discussed, the addition of an organic component would provide improved properties and maintain/speed up the degradation process of these materials.

\subsubsection{Impact on Polymer Properties}

Bone, feather and meal were shown to contain numerous organic and inorganic materials relevant for applications in polymer processing. (either as fillers or functional additives with the potential to improve material properties, Table 4). While the percentage addition of these materials differs both bone and meal have potential to be used in $40 \%$ wt. loadings (Kane et al., 2008), while feathers can be used up to $60 \%$ wt. (Reddy and Yang, 2010).

Improvements can be realized in mechanical, processability or disposal (end of life) properties, amongst others, which can be manipulated to meet design requirements. As mentioned, the efficiency of a functional additive in a polymer (Xanthos, 2010) is affected by particle 1) size, 2) shape, 3) surface area and 4) its compatibility with the base polymer. Both bone and meal contain inorganics including hydroxyapatite, potassium bicarbonate, sodium fluoride and other useful minerals. These constituent components, along with a consistent powder size for both materials, have already shown compatibility with a range of polymers and provided additional and improved mechanical properties (tensile, flexural and hardness - Table 4). These waste streams also contain organic proteins that could be used as bio-degradation aids to avoid long polymer degradation periods in landfill. Feathers are the most versatile of the three poultry waste materials for polymer use. In fibre form, the most desirable particle type (continuous additives), they can provide fibre reinforcement when used as a polymer filler. This reinforcement can improve tensile and flexural properties with a range of polymers in compositions up to 60\% (Reddy and Yang, 2010). 


\subsection{Energy, Carbon and Cost Implications}

Based on dry yield values of the three poultry waste streams (gained from LOI), it was calculated that $1,697,478 \mathrm{~kg} /$ day of dry poultry waste are generated within the UK. Compared to the $95.9 \mathrm{MJ}$ needed to generate $1 \mathrm{~kg}$ of polypropylene feedstock (Appendix 1), the poultry waste polymers had much lower energy inputs, i.e. $47.0-65.5 \mathrm{MJ} / \mathrm{kg}$ compared to $95.9 \mathrm{MJ} / \mathrm{kg}$ (Table 5), and almost 130,000 GJ/day of energy could be saved by displacing conventional polymer feedstock with poultry waste feedstock. Significant decreases in carbon emissions also occur (Table 6), with values of $1.60-2.40 \mathrm{kgCO}_{2} \mathrm{e} / \mathrm{kg}$ for poultry-waste polymers compared to $3.96 \mathrm{kgCO}_{2} \mathrm{e} / \mathrm{kg}$ for polypropylene, resulting in savings of between 40 and $60 \%$ (when using wind generated electricity). A total of $6645 \mathrm{tCO}_{2} \mathrm{e}$ could be saved per day through use of bone, meal and feathers. Even considering a scenario of using grid electricity (higher carbon emissions than via wind generation) a total saving of $4470 \mathrm{tCO}_{2} \mathrm{e}$ can be achieved.

Table 5. Potential daily energy savings if UK poultry waste streams were utilized as a polymer feedstock.

\begin{tabular}{|c|c|c|c|c|c|c|}
\hline $\begin{array}{c}\text { Waste } \\
\text { stream }\end{array}$ & $\begin{array}{c}\text { Poultry } \\
\text { polymer } \\
\text { production } \\
(\mathrm{MJ} / \mathrm{kg})^{1}\end{array}$ & $\begin{array}{c}\text { Saving per } \\
\text { kg of } \\
\text { polymer } \\
(\mathrm{MJ} / \mathrm{kg})^{2}\end{array}$ & $\begin{array}{c}\text { Raw waste } \\
\text { per kg } \\
\text { polymer } \\
\text { (kg) }\end{array}$ & $\begin{array}{c}\text { Saving per } \\
\text { kg of waste } \\
\text { used } \\
(\mathrm{MJ} / \mathrm{kg})^{3}\end{array}$ & $\begin{array}{c}\text { UK } \\
\text { production } \\
\text { (kgDM/day) } \\
4\end{array}$ & $\begin{array}{c}\text { Total } \\
\text { energy } \\
\text { saving } \\
(G J)^{5}\end{array}$ \\
\hline Bone & 65.45 & 30.45 & 0.40 & 76.13 & $1,109,311$ & 84,452 \\
\hline Meal & 65.33 & 30.57 & 0.40 & 76.43 & 486,643 & 37,194 \\
\hline Feather & 46.99 & 48.91 & 0.60 & 81.52 & 101,524 & 8,276 \\
\hline
\end{tabular}

${ }^{1}$ Obtained from calculations in Appendix $1 .{ }^{2}$ Difference in production energy between polypropylene and poultry-based polymers. ${ }^{3}$ Savings per kilogram of polymer divided by poultry waste quantity. ${ }^{4}$ Based on 1.1 billion birds slaughtered annually in UK (Department for Environment Food \& Rural Affairs, 2020). ${ }^{5}$

Calculated using equation in Box 1.

Table 6. Potential daily $\mathrm{CO}_{2}$ e savings if UK poultry waste streams were utilized as a polymer feedstock.

\begin{tabular}{|c|c|c|c|c|c|c|}
\hline $\begin{array}{l}\text { Waste } \\
\text { stream }\end{array}$ & $\begin{array}{c}\text { Poultry } \\
\text { polymer } \\
\text { production } \\
\left(\mathrm{kgCO}_{2} \mathrm{e} / \mathrm{kg}\right)^{1}\end{array}$ & $\begin{array}{c}\text { Saving per } \\
\text { kg of } \\
\text { polymer } \\
\left(\mathrm{kgCO}_{2} \mathrm{e} / \mathrm{kg}\right)^{2}\end{array}$ & $\begin{array}{c}\text { Raw waste } \\
\text { per kg } \\
\text { polymer (kg) }\end{array}$ & $\begin{array}{c}\text { Saving per } \\
\text { kg of waste } \\
\text { used } \\
\left(\mathrm{kgCO}_{2} \mathrm{e} / \mathrm{kg}\right)^{3}\end{array}$ & $\begin{array}{c}\text { UK } \\
\text { production } \\
(\mathrm{kgDM} / \mathrm{day})^{4}\end{array}$ & $\begin{array}{c}\text { Total } \mathrm{CO}_{2} \mathrm{e} \\
\text { saving } \\
\text { (tonneCO} \\
5\end{array}$ \\
\hline Bone & 2.395 & 1.565 & 0.40 & 3.91 & $1,109,311$ & 4337 \\
\hline Meal & 2.394 & 1.566 & 0.40 & 3.92 & 486,643 & 1908 \\
\hline Feather & 1.596 & 2.364 & 0.60 & 3.94 & 101,524 & 400 \\
\hline & & & & & $1,697,478$ & 6645 \\
\hline
\end{tabular}


${ }^{1}$ Obtained from calculations in Appendix 1. ${ }^{2}$ Difference in carbon emissions between polypropylene and poultry-based polymers. ${ }^{3}$ Savings per kilogram of polymer divided by poultry waste quantity. ${ }^{4}$ Based on 1.1 billion birds slaughtered annually in UK (Department for Environment Food \& Rural Affairs, 2020). ${ }^{5}$

Calculated using equation in Box 1.

The production costs of poultry waste materials are much lower than the purchase price of traditional polymer fillers. Bone, meal and feather fillers can be produced for 4.4, 4.3 and $3.2 \mathrm{p} / \mathrm{kg}$ respectively. This is notably lower than for common polymer fillers such as calcium carbonate (purchase price of between $31-39$ p/kg (Lee et al., 2020)), talc (12 - 51 p/kg (Gonzalez De Gortari et al., 2020)) or kaolin (13 p/kg (Jafari et al., 2020)). The final cost of poultry waste polymers is also lower than for oil-derived polymers, i.e. $49.9-73.8 \mathrm{p} / \mathrm{kg}$ compared to $120 \mathrm{p} / \mathrm{kg}$ (Table 7). This means that poultry waste can provide savings of between 38 and 58\%. Using UK production of bone, meal and feather materials, the total daily saving to the polymer industry would be $\sim £ 1,960,000$ (Table 7 ). With poultry waste streams currently being used for low-value applications, this shows the possibility for improved financial gain to both the polymer and poultry industries.

Based on a daily saving of $\sim £ 1,960,000$, the savings over a month would be sufficient to employ 1336 workers (at $£ 44,000 / y r$ ) for a year. To put this into context Biffa Group, the largest waste management company in the UK (which processes over 7 times more waste materials per year) employs 6000 employees (Biffa, 2020).

Table 7. Potential daily cost saving if UK poultry waste streams were utilized as a polymer feedstock.

\begin{tabular}{|c|c|c|c|c|c|c|}
\hline $\begin{array}{c}\text { Waste } \\
\text { stream }\end{array}$ & $\begin{array}{c}\text { Poultry } \\
\text { polymer } \\
\text { production } \\
(\mathbf{p} / \mathrm{kg})^{1}\end{array}$ & $\begin{array}{c}\text { Saving per } \\
\text { kg of } \\
\text { polymer } \\
(p / k g)^{2}\end{array}$ & $\begin{array}{c}\text { Raw waste } \\
\text { per kg } \\
\text { polymer } \\
\text { (kg) }\end{array}$ & $\begin{array}{l}\text { Saving per } \\
\text { kg of waste } \\
\text { used }(p / k g)^{3}\end{array}$ & $\begin{array}{c}\text { UK } \\
\text { production } \\
\text { (kgDM/day) } \\
4\end{array}$ & $\begin{array}{l}\text { Total cost } \\
\text { saving }(\mathfrak{f})^{5}\end{array}$ \\
\hline Bone & 73.75 & 46.25 & 0.40 & 115.63 & $1,109,311$ & $1,282,696$ \\
\hline Meal & 73.72 & 46.28 & 0.40 & 115.70 & 486,643 & 563,046 \\
\hline Feather & 49.91 & 70.09 & 0.60 & 116.82 & 101,524 & 118,600 \\
\hline & & & & & $1,697,478$ & $1,964,342$ \\
\hline
\end{tabular}

${ }^{1}$ Obtained from calculations in Appendix 1. ${ }^{2}$ Difference in production costs between polypropylene and poultry-based polymers. ${ }^{3}$ Savings per kilogram of polymer divided by poultry waste quantity. ${ }^{4}$ Based on 1.1 billion birds slaughtered annually in UK (Department for Environment Food \& Rural Affairs, 2020). ${ }^{5}$

Calculated using equation in Box 1.

Based on possible energy generation values from these techniques, it was calculated that bone, meal and feathers can potentially displace between around 418 and 761 tonnes of oil 
equivalent (toe) per day (Table 8), depending on what techniques were used. In comparison, if daily amount of bone, meal and feathers were used for polymer production (based on 2.29 $\mathrm{kg}$ of oil needed per kilogram of polypropylene), 3887 tonnes of oil equivalent would be saved per day. The displacement of oil using the poultry wastes as a polymer feedstock is over five times higher than when the wastes are used as a bioenergy source.

Table 8. Potential daily oil displacement poultry bone, meal and feather (within UK).

\begin{tabular}{|c|c|c|c|c|}
\hline Waste stream & $\begin{array}{c}\text { Energy } \\
\text { conversion } \\
\text { process }\end{array}$ & Product & $\begin{array}{c}\text { Energy output } \\
\text { (MJ/kgDM) }\end{array}$ & $\begin{array}{c}\text { Oil displaced } \\
\text { (toe/day) }^{1}\end{array}$ \\
\hline \multirow{2}{*}{ Bone and Meal } & Combustion & Heat & $19^{2,3}$ & 724 \\
\hline & Pyrolysis & Bio-oil & $10^{4}$ & 381 \\
\hline Feathers & Gasification & Syngas & $15.2^{5}$ & 37 \\
\hline Total (high-value) & \multicolumn{3}{|c|}{ Bone and meal bio-oil + feather syngas } & 761 \\
\hline Total (high-saving) & \multicolumn{3}{|c|}{ Bone and meal heat + feather syngas } & 418 \\
\hline
\end{tabular}

McGlashan (2003). ${ }^{5}$ Based on energy output of 7.6 MJ/kgDM for feathers (assumes gasifier losses of 3.89\%)

(Kwiatkowski et al., 2013).

\subsubsection{Impact for Industry}

A pressing sustainability issue for the polymer industry at present is the reliance on oil supplies needed for plastic production. The use of converted poultry waste as high load filler/additives can provide significant savings in oil usage. Research has shown poultry waste streams can be directly inputted to the polymer mix at high loadings (>40\% wt.). For instance, bone can be used in loadings of $40 \%$ with a range of polymers. This means that if producing $1 \mathrm{~kg}$ of polypropylene, $0.4 \mathrm{~kg}$ of bone can be used to directly replace $0.4 \mathrm{~kg}$ of plastic feedstock. With $2.29 \mathrm{~kg}$ of oil needed per kilogram of polypropylene (Ashby, 2013), use of $0.4 \mathrm{~kg}$ of bone saves $\sim 0.9 \mathrm{~kg}$ of crude oil. The direct replacement of bone, meal and feathers for plastic feedstock, would save 3887 tonnes of oil equivalent per day. In comparison, if these poultry waste streams were used as a renewable energy source, only 761 tonnes of oil equivalent would be saved (Table 8), less than $20 \%$ of what is achievable via using the wastes for polymer feedstock. This verifies the suitability for poultry waste as a polymer substitute compared to as an energy source. Given the issues with diminishing oil supplies (Greene et al., 2006), the estimated oil savings and financial gains achieved from using poultry-based polymer materials are promising. 
A further benefit is the savings achievable due to the reduced processing energy demands of poultry-based polymers compared to conventional polymers. Calculations determined that use of 1 day's UK bone, offal and feather waste $(1,697,478 \mathrm{~kg})$ has the potential to reduce energy demand by 129,922 GJ or 3105 tonnes of oil equivalent (Table 5). To put this energy value into context, this saving in energy footprint is equivalent to almost $24 \%$ of the total weekly electric consumption of Northern Ireland (Department for the Economy, 2019). The additions of poultry waste streams as a polymer filler also provides a significant carbon emission saving. Upwards of 6645 tonnes of $\mathrm{CO}_{2} \mathrm{e}$ emissions could be avoided daily through use of the three selected poultry waste materials.

Another current issue for the poultry industry is the low (or in some cases negative) value of waste streams. However, use as a polymer feedstock material, whether as a filler, functional additive or as a precursor material, results in a reduction in polymer production costs. Analysis reviewed the cost savings when utilizing poultry waste as an additive to replace traditional polymer feedstock. The results showed that using poultry waste streams as polymer filler feedstock provided greater value than current disposal methods, i.e. meal production. Production costs in transforming poultry waste streams into polymer feedstock are lower $(38-58 \%)$ due to the large volume of poultry by-products created and the minimal processing required. This reduction means that if the daily UK feather, bone and meal produced was used as polymer filler, it would save $£ 1,964,000$ in raw polymer feedstock costs. This outlines the benefit to the poultry industry by adding value to waste streams, and to the polymer industry by replacing higher cost oil-based feedstock. Given that poultry waste contains numerous minerals that could provide additional properties, the research shows that overall, these materials have significant potential for use in the polymer industry.

\subsection{Limitations and Future Work}

An increasing strain on finite petroleum resources, fluctuations in oil prices, increasing levels of environmental pollution, a shortage of landfill sites, increased environmental legislation and taxation have, in combination, instigated a pressing need to reduce to 1) reduce the burden on petroleum feedstocks and 2) develop biobased alternatives. The use of agri-waste streams represents a viable avenue to develop solutions for both. This correlates with a growing global filler market, expected to see a Compound Annual Growth Rate (CAGR) of $3.8 \%$ between 2019-2024 (reaching $\$ 58$ billion in 2024), fueled by an increasing demand for organic fillers such as natural fibres, wood flour and hemp (TechSci Research, 2019). 
While the current research investigated the use of poultry-waste fillers up to $40 \%$, a limitation of the work was that it did not go beyond this. It is the use of agricultural waste streams as $100 \%$ biopolymer (0\% petroleum) precursors that is most exciting. These biobased resources, at present posing the industry a commercial and environmental challenge in regard to their effective disposal, contain the building blocks for the development of natural polymers and represent a source of sustainable raw materials. At present they are simply underutilised. Their availability across the globe is in stark contrast with the enormous disparities, and resulting turmoil, associated with worldwide distribution of fossil resources. Moving forward (in this context) the authors aim to demonstrate the feasibility of chemically modifying and thermally processing (via extrusion) protein-based biopolymers. The preliminary techno-economic-environmental analysis undertaken for the current work focused on energy, carbon and cost, and found positive benefits on all fronts from the move to biobased polymers. However, future research on materials currently under development should encompass a broader range of environmental impacts as part of a comprehensive life cycle assessment. More detailed investigation of the socioeconomic impacts may also prove beneficial, as the development of an industry based on the use of poultry wastes for biopolymer production could help to support a number of UN Sustainable Development Goals, including Decent Work and Economic Growth (SDG 8) and Industry, Innovation and Infrastructure (SDG 9), as well as aligning with other goals of Responsible Production and Consumption (SDG 12) and Climate Action (SDG 13).

\section{Conclusions}

This paper sought to investigate alternative uses for poultry waste, which due to an expanding industry has now reached 68 million tonnes per year worldwide. In the past, the waste-to-bioenergy route has often been favoured for agricultural wastes, but these wastes can also be used for production of novel biomaterials. All three of the wastes investigated (bone, meal and feathers) hold considerable potential for the polymer industry, with characterisation testing showing the presence of organic and inorganic components and strong suitability for use as fillers or functional additives. In the case of feathers, there is 
additional potential for the creation of bio-based petroleum-free polymers. Energy and carbon savings of $129,922 \mathrm{GJ}$ and 6645 tonnes $\mathrm{CO}_{2} \mathrm{e}$ could be saved daily by using these $\mathrm{UK}$ waste materials. Through replacement of fossil feedstock with these three poultry wastes, oil savings are 5 times higher than those achievable for the waste-to-bioenergy route. This is the case when comparing to direct combustion for heat production and advanced processes generating added value products including syngas and bio-oil. Coupled with oil savings, use of poultry wastes for polymer production could result in financial gain to both the polymer and poultry industries, estimated at over $£ 1,964,000$ per day in the UK alone. The research shows the environmental and economic value of poultry wastes and highlights the important role the biomaterials sector could play in tackling environmental issues.

\section{Acknowledgments:}

The authors would like to acknowledge financial backing from the Department for the Economy (DFE) and Moy Park (Armagh, UK) for their contribution of material supplies. The authors would also like to thank Rawan Hakawati for preliminary work on energy conversion.

\section{References}

Alibaba.com, 2019. Industrial Mixer [WWW Document]. URL https://www.alibaba.com/product-detail/BigVertical-Color-Mixer-Plastic-Material_748370241.html (accessed 4.16.19).

Ashby, M.F., 2013. Materials and the Environment - Eco-Informed Material Choice, 2nd ed. Butterworth Heinemann, Oxford.

Asuke, F., Aigbodion, V.S., Abdulwahab, M., Fayomi, O.S.I., Popoola, A.P.I., Nwoyi, C.I., Garba, B., 2012. Effects of bone particle on the properties and microstructure of polypropylene/bone ash particulate composites. Results Phys. 2, 135-141. https://doi.org/10.1016/j.rinp.2012.09.001

Awonorin, S.O., Ayoade, J.A., Bamiro, F.O., Oyewole, L.O., 1995. Relationship of rendering process temperature and time to selected quality parameters of poultry by-product meal. LWT - Food Sci. Technol. 28, 129-134. https://doi.org/10.1016/S0023-6438(95)80024-7

Bain, M., Brass, D., Gill, R., Pollet, B., Isaac, D., 2018. Calcium pidolate improves egg quality when it is fed to commercial layers from 50 weeks of age. 29th Annu. Aust. Poult. Sci. Symp.

Bethanis, S., Cheeseman, C.R., Sollars, C.J., 2002. Properties and microstructure of sintered incinerator bottom ash $28,881-886$.

Biffa, 2020. Providing critical, sustainable infrastructure and services.

Binhussain, M.A., El-Tonsy, M.M., 2013. Palm leave and plastic waste wood composite for out-door structures. Constr. Build. Mater. 47, 1431-1435. https://doi.org/10.1016/j.conbuildmat.2013.06.031

Bolan, N.S., Szogi, A.A., Chuasavathi, T., Seshadri, B., Rothrock, M.J., Panneerselvam, P., 2010. Uses and management of poultry litter. Worlds. Poult. Sci. J. 66, 673-698. https://doi.org/10.1017/S0043933910000656 
Casano, G., Piva, S., 2016. Effect of Sodium bicarbonate on Fire behaviour of filled E- Glass Reinforced Epoxy Composites. IOP Conf. Ser. Mater. Sci. Eng. 0-6. https://doi.org/10.1088/1757-899X/149/1/012120

Chae, D.W., Kim, B.C., 2005. Characterization on polystyrene/zinc oxide nanocomposites prepared from solution mixing. Polym. Adv. Technol. 16, 846-850. https://doi.org/10.1002/pat.673

Compassion in World Farming, 2018. Statistics : Broiler Chickens.

Davis, G., Song, J.H., 2006. Biodegradable packaging based on raw materials from crops and their impact on waste management. Ind. Crops Prod. 23, 147-161. https://doi.org/10.1016/j.indcrop.2005.05.004

Department for Business. Energy \& Industrial Strategy, 2020. Greenhouse gas reporting: conversion factors 2020.

Department for Environment Food \& Rural Affairs, 2020. United Kingdom Poultry and Poultry Meat Statistics - December 2019. https://doi.org/10.1017/CBO9781107415324.004

Department for the Economy, 2019. Electricity Consumption and Renewable Generation in Northern Ireland: Year Ending December 2018 1-6.

Dietrich, K., Dumont, M.J., Del Rio, L.F., Orsat, V., 2017. Producing PHAs in the bioeconomy — Towards a sustainable bioplastic. Sustain. Prod. Consum. 9, 58-70. https://doi.org/10.1016/j.spc.2016.09.001

European Parliament, 2009a. Directive 2009/28/EC of the European Parliament and of the Council of 23 April 2009 on the promotion of the use of energy from renewable sources and amending and subsequently repealing Directives 2001/77/EC and 2003/30/EC.

European Parliament, 2009b. Directive 2009/29/EC of the European Parliament and of the council of 23 april 2009 ammending Directive 2003/87/EC so as to improve and extend the greenhouse gas emission allowance trading scheme of the Community, Official Journal of the European Union.

European Parliament, 2008. Directive 2008/98/EC of the European Parliament and of the Council on waste and repealing certain directives, Official Journal of the European Union. https://doi.org/2008/98/EC.; 32008 L0098

Eurostat, 2018. Greenhouse gas emission statistics - emission inventories [WWW Document]. Eurostat. URL http://ec.europa.eu/eurostat/statistics-explained/index.php/Greenhouse_gas_emission_statistics (accessed 1.5.18).

Eurostat, 2015. Each person in the EU generated $481 \mathrm{~kg}$ of municipal waste in 2013 54-56.

Food and Agriculture Organization of the United Nations, 2019. Meat market review.

Gonzalez De Gortari, M., Rodriguez-Uribe, A., Misra, M., Mohanty, A.K., 2020. Insights on the structureperformance relationship of polyphthalamide (PPA) composites reinforced with high-temperature produced biocarbon. RSC Adv. 10, 26917-26927. https://doi.org/10.1039/d0ra03629c

Greene, D.L., Hopson, J.L., Li, J., 2006. Have we run out of oil yet? Oil peaking analysis from an optimist's perspective. Energy Policy 34, 515-531. https://doi.org/10.1016/j.enpol.2005.11.025

Hammond, G., Jones, C., 2011. Inventory of Carbon \& Energy (ICE) Version 2.0.

Heiri, O., Lotter, A., Lemcke, G., 2001. Loss on ignition as a method for estimating organic and carbonate content. J. Paleolimnol. 25, 101-110.

Hood, C.M., Healy, M.G., 1994. Bioconversion of waste keratins: wool and feathers. Resour. Conserv. Recycl. 11, 179-188.

Igarza, E., Pardo, S.G., Abad, M.J., Cano, J., Galante, M.J., Pettarin, V., Bernal, C., 2014. Structure-fracture properties relationship for Polypropylene reinforced with fly ash with and without maleic anhydride functionalized isotactic Polypropylene as coupling agent. Mater. Des. 55, 85-92. https://doi.org/10.1016/j.matdes.2013.09.055 
Jafari, B., Abbasi, M., Hashemifard, S.A., 2020. Development of new tubular ceramic microfiltration membranes by employing activated carbon in the structure of membranes for treatment of oily wastewater. J. Clean. Prod. 244, 118720. https://doi.org/10.1016/j.jclepro.2019.118720

Jayathilakan, K., Sultana, K., Radhakrishna, K., Bawa, A.S., 2012. Utilization of byproducts and waste materials from meat, poultry and fish processing industries: A review. J. Food Sci. Technol. 49, 278-293. https://doi.org/10.1007/s13197-011-0290-7

Jepspectro.com, 2016. Oxide - Carbonate - Element Conversion Table [WWW Document]. jepspectro.com. URL http://www.jepspectro.com/electron_microprobe/oxide_conversion.htm (accessed 3.12.19).

Kane, R.J., Converse, G.L., Roeder, R.K., 2008. Effects of the reinforcement morphology on the fatigue properties of hydroxyapatite reinforced polymers. J. Mech. Behav. Biomed. Mater. 1, 261-268. https://doi.org/10.1016/j.jmbbm.2008.01.004

Kantarli, I.C., Kabadayi, A., Ucar, S., Yanik, J., 2016. Conversion of poultry wastes into energy feedstocks. Waste Manag. 56, 530-539. https://doi.org/10.1016/j.wasman.2016.07.019

Kantharia, N., Naik, S., Apte, S., Kheur, M., Kheur, S., Kale, B., 2014. Nano-hydroxyapatite and its contemporary applications. Bone $34,1-71$.

KLM Technology Group, 2014. General Process Plant (Engineering Design Guideline) 1-22.

Kwiatkowski, K., Krzysztoforski, J., Bajer, K., Dudyński, M., 2013. Bioenergy from feathers gasification Efficiency and performance analysis. Biomass and Bioenergy 59, 402-411. https://doi.org/10.1016/j.biombioe.2013.07.013

Lee, J., Ryu, K.H., Ha, H.Y., Jung, K.D., Lee, J.H., 2020. Techno-economic and environmental evaluation of nano calcium carbonate production utilizing the steel slag. J. CO2 Util. 37, 113-121. https://doi.org/10.1016/j.jcou.2019.12.005

Leip, A., Weiss, F., T. Wassenaar, Perez, I., Fellmann, T., Loudjani, P., Tubiello, F., Grandgirard, D., Monni, S., Biala, K., 2010. Evaluation of the livestock sector's contribution to the EU greenhouse gas emissions (GGELS) - final report. 32.

Lukubira, S., Ogale, A., 2014. Calendered linear low-density polyethylene consolidated meat and bone meal composites. J. Appl. Polym. Sci. 131, 14-16. https://doi.org/10.1002/app.41145

Ma, Q., Paudel, K.P., Bhandari, D., Theegala, C., Cisneros, M., 2019. Implications of poultry litter usage for electricity production. Waste Manag. 95, 493-503. https://doi.org/10.1016/j.wasman.2019.06.022

MadeinChina.com, 2019. Industrial Dryer [WWW Document]. URL https://tztjcherry.en.made-inchina.com/product/moZJEjwHCeWa/China-10kg-500kg-Industrial-Laundry-Spin-Dryer-Ss-HydroWater-Extractor.html (accessed 4.16.19).

McGauran, T., Dunne, N., Smyth, B.M., Cunningham, E., 2020. Incorporation of poultry eggshell and litter ash as high loading polymer fillers in polypropylene. Compos. Part C Open Access 3, 100080. https://doi.org/10.1016/j.jcomc.2020.100080

McGlashan, S.A., 2003. Industrial and Energy Uses of Animal By-Products, Past and Future. Essent. Render. 229-243.

McLachlan, J., MacLeod, G., 1959. The Use of Conversion Factors for the Determination Concentration of Nutrients in Culture Media. Limnol. Oceanogr. 4, 218-219.

Medugu, C.I., Kwari, I.D., Igwebuike, J., Nkama, I., Mohammed, I.D., Hamaker, B., Science, A., 2010. Performance and economics of production of broiler chickens fed sorghum or millet as replacement for maize in the semi-arid zone of Borno State Agricultural Development Programme ( BOSADP ) Maiduguri Department of Food Science and Technology, University 3-6. 
Monforti-Ferrario, F., Dallemand, J.-F., Pascua, I.P., Motola, V., Banja, M., Scarlat, N., Medarac, H., Castellazzi, L., Labanca, N., Bertoldi, P., Pennington, D., Goralczyk, M., Schau, E.M., Saouter, E., Sala, S., Notarnicola, B., Tassielli, G., Renzulli, P., 2015. Energy use in the EU food sector: State of play and opportunities for improvement. https://doi.org/10.2790/158316

Murariu, M., Da Silva Ferreira, A., Degée, P., Alexandre, M., Dubois, P., 2007. Polylactide compositions. Part 1: Effect of filler content and size on mechanical properties of PLA/calcium sulfate composites. Polymer (Guildf). 48, 2613-2618. https://doi.org/10.1016/j.polymer.2007.02.067

Musselman, L.L., Greene, H.L., 1996. Materials for use as fire retardant additives. U.S. Patent 5480587 A.

Nayak, P.L., 1999. Biodegradable Polymers: Opportunities and Challenges. J. Macromol. Sci. Part C 39, 481505.

Ng, K.S., Sadhukhan, J., 2017. Special issue: Sustainable availability and utilisation of wastes. Sustain. Prod. Consum. 9, 1-2. https://doi.org/10.1016/j.spc.2017.01.002

Phyllis2, 2017. Database for Biomass and Waste [WWW Document]. Energy Res. Cent. Netherlands. URL https://www.ecn.nl/phyllis2/Browse/Standard/ECN-Phyllis\#bone (accessed 7.5.17).

Piazza, G.J., McAloon, A.J., Garcia, R.A., 2011. A renewable flocculant from a poultry slaughterhouse waste and preliminary estimate of production costs. Resour. Conserv. Recycl. 55, 842-848. https://doi.org/10.1016/j.resconrec.2011.04.004

Plasteurope.com, 2019. Polymer prices [WWW Document]. URL https://www.plasteurope.com/prices/ (accessed 4.16.19).

Plastics Europe, 2019. Plastics - the Facts 2019 [WWW Document]. URL https://www.plasticseurope.org/en/resources/market-data

Queen's University Belfast, 2020. Human Resources [WWW Document]. URL https://www.qub.ac.uk/directorates/HumanResources/hr-filestore/Filetoupload,866065,en.pdf\%0A

Quina, M.J., Soares, M.A.R., Quinta-Ferreira, R., 2017. Applications of industrial eggshell as a valuable anthropogenic resource. Resour. Conserv. Recycl. 123, 176-186. https://doi.org/10.1016/j.resconrec.2016.09.027

Reddy, N., 2015. Non-food industrial applications of poultry feathers. Waste Manag. 45, 91-107. https://doi.org/10.1016/j.wasman.2015.05.023

Reddy, N., Yang, Y., 2010. Light-weight polypropylene composites reinforced with whole chicken feathers. Appl. Polym. 116, 3668-3675.

Restch, 2013. Rotor Beater Mill SR 200 Rotor Beater Mill SR 200.

Scherer, C., Emberger-Klein, A., Menrad, K., 2017. Biogenic product alternatives for children: Consumer preferences for a set of sand toys made of bio-based plastic. Sustain. Prod. Consum. 10, 1-14. https://doi.org/10.1016/j.spc.2016.11.001

Shogren, R., Wood, D., Orts, W., Glenn, G., 2019. Plant-based materials and transitioning to a circular economy. Sustain. Prod. Consum. 19, 194-215. https://doi.org/10.1016/j.spc.2019.04.007

Sienkiewicz, M., Janik, H., Borzędowska-Labuda, K., Kucińska-Lipka, J., 2017. Environmentally friendly polymer-rubber composites obtained from waste tyres: A review. J. Clean. Prod. 147, 560-571. https://doi.org/10.1016/j.jclepro.2017.01.121

Stingone, J.A., Wing, S., 2011. Poultry Litter Incineration as a Source of Energy: Reviewing the Potential for Impacts on Environmental Health and Justice. New Solut. A J. Environ. Occup. Heal. Policy 21, $27-42$. https://doi.org/10.2190/NS.21.1.g

Sustainable Energy Authority of Ireland, 2015. Commercial / Industrial Fuels Comparison of Energy Costs 
Commercial / Industrial Fuels Comparison of Useful Energy Costs for Space Heating 54-55.

TechSci Research, 2019. Global Polymer Filler Market By Type (Hydroxides, Salts, Oxides, Natural Fibers, Silicates, Metals and Others), By End User (Construction, Manufacturing, Automotive, Packaging and Others), By Region, Competition, Forecast \& Opportunities, 2024.

Thompson, R.C., Swan, S.H., Moore, C.J., vom Saal, F.S., 2009. Our plastic age. Philos. Trans. R. Soc. B Biol. Sci. 364, 1973-1976. https://doi.org/10.1098/rstb.2009.0054

Tibaland, 2019. Carbonate and Oxide Elements Conversion Table [WWW Document]. tibaland.co. URL http://www.tibaland.co/services/carbonate-oxide-elements-conversion-table/ (accessed 3.12.19).

Toro, P., Quijada, R., Arias, L., Yazdani-Pedram, M., 2007. Mechanical and Morphological Studies of Poly(propylene) -Filled Eggshell Composites. Macromol. Mater. Eng. 292, 1027-1034. https://doi.org/10.1002/mame.200700147

Treinyte, J., Bridziuviene, D., Fataraite-Urboniene, E., Rainosalo, E., Rajan, R., Cesoniene, L., Grazuleviciene, V., 2018. Forestry wastes filled polymer composites for agricultural use. J. Clean. Prod. 205, 388-406. https://doi.org/10.1016/j.jclepro.2018.09.012

Wang, Y., Sun, T., 2012. Life cycle assessment of CO 2 emissions from wind power plants: Methodology and case studies. Renew. Energy 43, 30-36. https://doi.org/10.1016/j.renene.2011.12.017

Williams, C., Barker, J., Sims, J., 1999. Management and utilization of poultry wastes. Rev. Environ. Contam. Toxicol. 162, 105-157.

Xanthos, M., 2010. Functional Fillers for Plastics, 2nd ed. WILEY-VCH Verlag GmbH \& Co. KGaA.

Zhan, M., Wool, R.P., 2011. Mechanical properties of chicken feather fibers. Polym. Compos. 32, 937-944.

Zubov, P.I., Sukhareva, L.A., Voronkov, V.A., 1967. Effect of Quartz sand filler on the mechanical and thermophysical properties of alkyd and epoxy coatings. Mekhanika Polim. 3, 507-510. 


\section{Appendix 1}

Bone Polymers (40\% Bone / 60\% Plastic)

Energy Requirements

\begin{tabular}{|c|c|c|c|}
\hline & $\begin{array}{c}\text { Energy Needed }{ }^{1} \\
(\mathrm{MJ} / \mathrm{kg})\end{array}$ & Weight Used (kg) & $\begin{array}{l}\text { Total } \\
\text { (MJ) }\end{array}$ \\
\hline \multicolumn{4}{|c|}{ Bone Powder Production } \\
\hline Cleaning ${ }^{2}$ & 0.30 & 0.40 & 0.12 \\
\hline Drying $^{3}$ & 2.88 & 0.40 & 1.15 \\
\hline Milling 4 & 0.36 & 0.40 & 0.14 \\
\hline \multicolumn{4}{|c|}{ Plastic Feedstock } \\
\hline Polypropylene $^{5}$ & 95.90 & 0.60 & 57.54 \\
\hline \multicolumn{4}{|c|}{ Polymer Generation } \\
\hline Mixing ${ }^{6}$ & 0.30 & 1.00 & 0.30 \\
\hline Extrusion $^{7}$ & 6.20 & 1.00 & 6.20 \\
\hline \multicolumn{3}{|c|}{ Total (Processing - excluding plastic feedstock) } & 7.91 \\
\hline \multicolumn{3}{|c|}{ Total (to produce $1 \mathrm{~kg}$ of polymer) } & 65.45 \\
\hline \multirow{3}{*}{\multicolumn{4}{|c|}{$\begin{array}{l}\text { Energy required }(\mathrm{MJ} / \mathrm{kg})=\{(\text { Power }(\mathrm{kW}) \times \text { Time }(\mathrm{hr})) / \text { Mass }(\mathrm{kg})\} \times 3.6^{2} \text { Based on cleaner with power output of } 5 \mathrm{~kW} \text { cleaning at a } \\
\text { rate of } 60 \mathrm{~kg} / \mathrm{hr}\left(\mathrm{KLM} \text { Technology Group, 2014) }{ }^{3} \text { Based on oven with a power output of } 10 \mathrm{~kW} \text { needing } 4 \text { hours to dry } 50 \mathrm{~kg} \text { of waste }\right. \\
\text { material (MadeinChina.com, 2019) }{ }^{4} \text { Based on cutting mill with power output of } 3 \mathrm{~kW} \text { with a processing rate of } 30 \mathrm{~kg} / \mathrm{hr}\left(\text { Restch, 2013) }{ }^{5}\right.\end{array}$}} \\
\hline & & & \\
\hline & & & \\
\hline \multirow{2}{*}{\multicolumn{4}{|c|}{$\begin{array}{l}\text { Embodied energy of polypropylene (Hammond and Jones, 2011) }{ }^{6} \text { Based on industrial mixer with a power output of } 10 \mathrm{~kW} \text { mixing } 120 \\
\mathrm{~kg} / \mathrm{hr} \text { (Alibaba.com, 2019) }{ }^{7} \text { Typical energy value for extruding polypropylene blends (Ashby, 2013) }\end{array}$}} \\
\hline $\mathrm{g} / \mathrm{hr}$ (Alibaba.com, 2019) ${ }^{7} \mathrm{~T}$ & & & \\
\hline
\end{tabular}

\section{Cost Requirements}

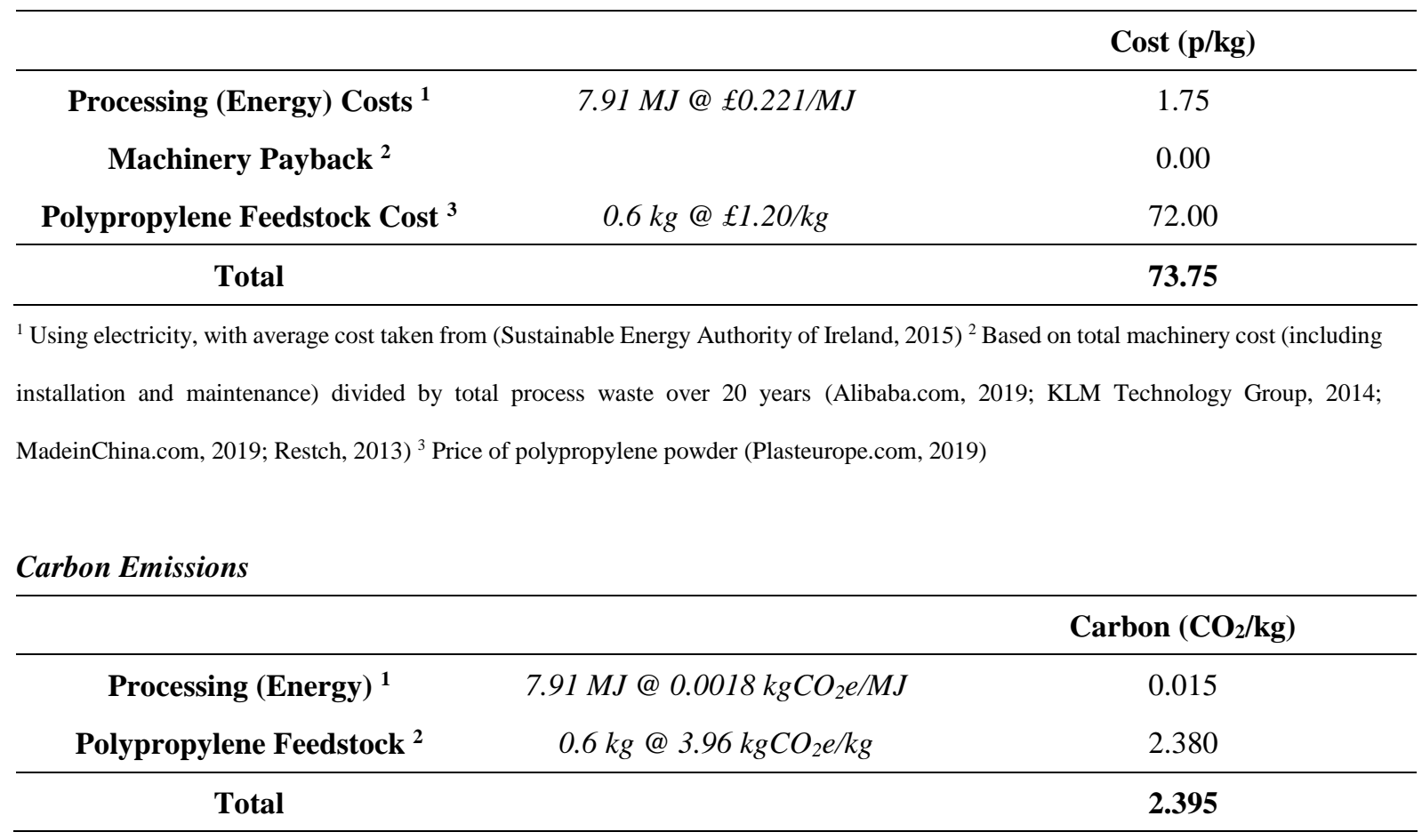


${ }^{1}$ Emission value based on machinery electricity energy generated via wind power (Wang and Sun, 2012) ${ }^{2}$ Emission based of typical value for polypropylene (Ashby, 2013)

Meal Polymers (40\% Meal / 60\% Plastic)

Energy Requirements

\begin{tabular}{|c|c|c|c|}
\hline & $\begin{array}{c}\text { Energy Needed }{ }^{1} \\
(\mathrm{MJ} / \mathrm{kg})\end{array}$ & Weight Used (kg) & $\begin{array}{l}\text { Total } \\
\text { (MJ) }\end{array}$ \\
\hline \multicolumn{4}{|c|}{ Bone Powder Production } \\
\hline Drying $^{2}$ & 2.88 & 0.40 & 1.15 \\
\hline Milling 3 & 0.36 & 0.40 & 0.14 \\
\hline \multicolumn{4}{|c|}{ Plastic Feedstock } \\
\hline Plastic $^{4}$ & 95.90 & 0.60 & 57.54 \\
\hline \multicolumn{4}{|c|}{ Polymer Generation } \\
\hline Mixing 5 & 0.30 & 1.00 & 0.30 \\
\hline Extrusion ${ }^{6}$ & 6.20 & 1.00 & 6.20 \\
\hline \multicolumn{3}{|c|}{ Total (Processing - excluding plastic feedstock) } & 7.79 \\
\hline \multicolumn{3}{|c|}{ Total (to produce $1 \mathrm{~kg}$ of polymer) } & 65.33 \\
\hline
\end{tabular}

${ }^{1}$ Energy required $(\mathrm{MJ} / \mathrm{kg})=\{($ Power $(\mathrm{kW}) \times$ Time $(\mathrm{hr})) /$ Mass $(\mathrm{kg})\} \times 3.6{ }^{2}$ Based on oven with a power output of $10 \mathrm{~kW}$ needing 4 hours to dry $50 \mathrm{~kg}$ of waste material (MadeinChina.com, 2019) ${ }^{3}$ Based on cutting mill with power output of $3 \mathrm{~kW}$ with a processing rate of $30 \mathrm{~kg} / \mathrm{hr}$ (Restch, 2013) ${ }^{4}$ Embodied energy of polypropylene (Hammond and Jones, 2011) ${ }^{5}$ Based on industrial mixer with a power output of $10 \mathrm{~kW}$ mixing $120 \mathrm{~kg} / \mathrm{hr}$ (Alibaba.com, 2019) ${ }^{6}$ Typical energy value for extruding polypropylene blends (Ashby, 2013)

Cost Requirements

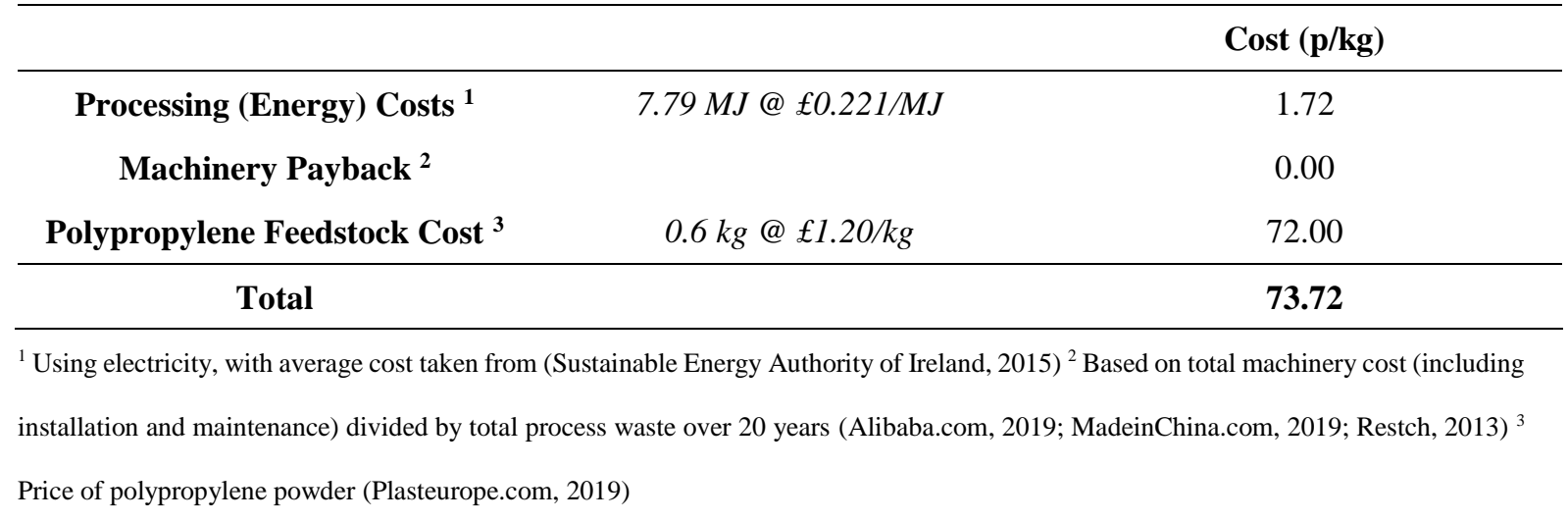

\section{Carbon Emissions}

\begin{tabular}{ccc}
\hline & & ${\text { Carbon }\left(\mathbf{C O}_{2} / \mathbf{k g}\right)}$ \\
\hline Processing (Energy) $^{\mathbf{1}}$ & $7.79 \mathrm{MJ} @ 0.0018 \mathrm{kgCO}_{2} \mathrm{e} / \mathrm{MJ}$ & 0.014 \\
Polypropylene Feedstock $^{2}$ & $0.6 \mathrm{~kg} @ 3.96 \mathrm{kgCO}_{2} e / \mathrm{kg}^{2}$ & 2.380 \\
\hline Total & $\mathbf{2 . 3 9 4}$ \\
\hline
\end{tabular}


${ }^{1}$ Emission value based on machinery electricity energy generated via wind power (Wang and Sun, 2012) ${ }^{2}$ Emission based of typical value for polypropylene (Ashby, 2013)

Feather Polymers (60\% Feather / 40\% Plastic)

Energy Requirements

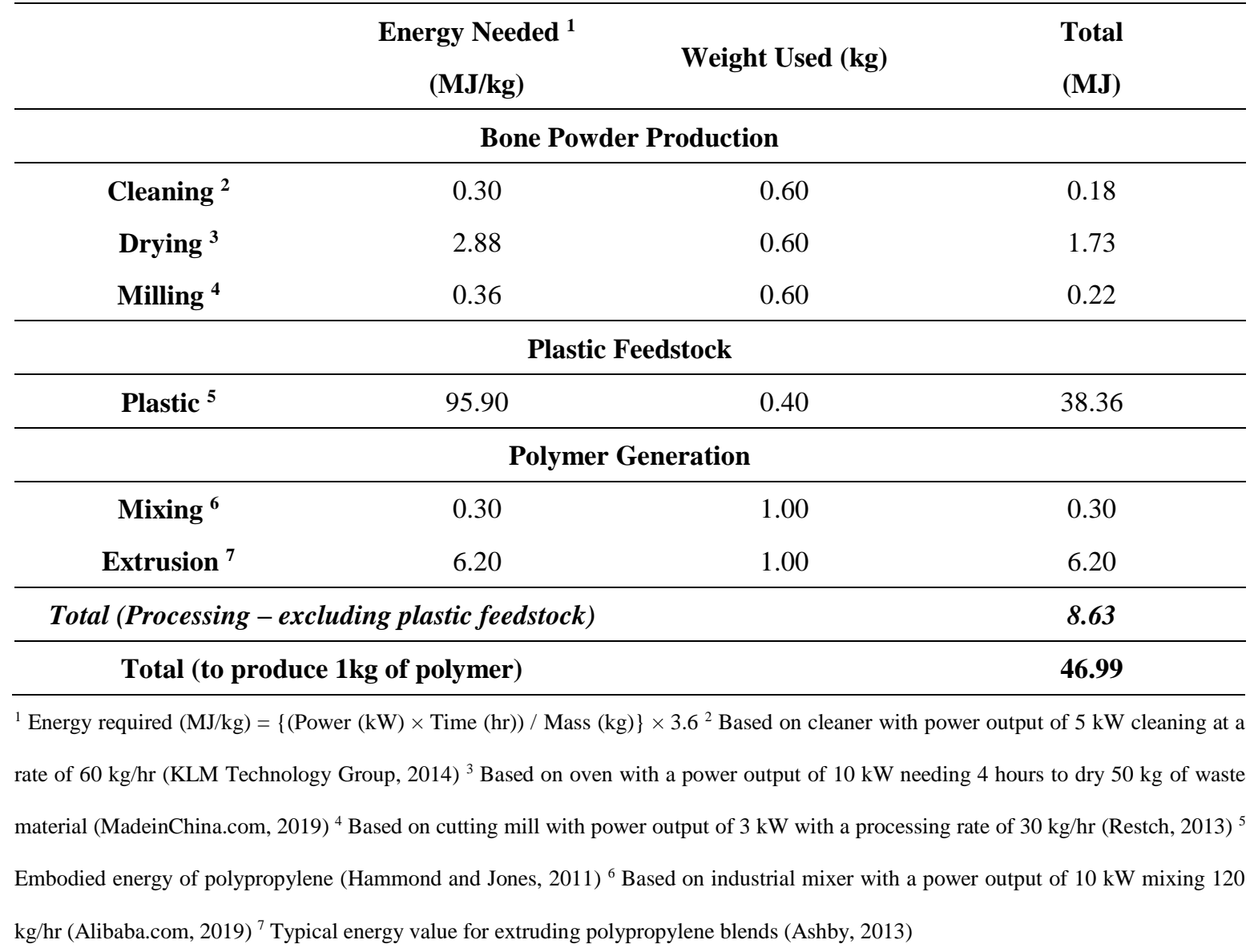

Cost Requirements

\begin{tabular}{ccc}
\hline & Cost (p/kg) \\
\hline Processing (Energy) Costs $^{1}$ & $8.63 \mathrm{MJ} @ £ 0.221 / \mathrm{MJ}$ & 1.91 \\
Machinery Payback $^{2}$ & & 0.00 \\
Polypropylene Feedstock Cost $^{3}$ & $0.4 \mathrm{~kg} @ £ 1.20 / \mathrm{kg}$ & 48.00 \\
\hline Total & $\mathbf{4 9 . 9 1}$ \\
\hline
\end{tabular}

${ }^{1}$ Using electricity, with average cost taken from (Sustainable Energy Authority of Ireland, 2015) ${ }^{2}$ Based on total machinery cost (including installation and maintenance) divided by total process waste over 20 years (Alibaba.com, 2019; KLM Technology Group, 2014; MadeinChina.com, 2019; Restch, 2013) ${ }^{3}$ Price of polypropylene powder (Plasteurope.com, 2019) 
Carbon $\left(\mathrm{CO}_{2} / \mathrm{kg}\right)$

\begin{tabular}{ccc}
\hline $\begin{array}{c}\text { Processing (Energy) } \\
\text { Polypropylene Feedstock }^{2}\end{array}$ & $8.63 \mathrm{MJ} @ 0.0018 \mathrm{kgCO}_{2} \mathrm{e} / \mathrm{MJ}$ & 0.016 \\
\hline Total & $0.4 \mathrm{~kg} @ 3.96 \mathrm{kgCO}_{2} \mathrm{e} / \mathrm{kg}$ & 1.580
\end{tabular}

${ }^{1}$ Emission value based on machinery electricity energy generated via wind power (Wang and Sun, 2012) ${ }^{2}$ Emission based of typical value for polypropylene (Ashby, 2013) 


\section{Appendix 2 \\ SEM Images}
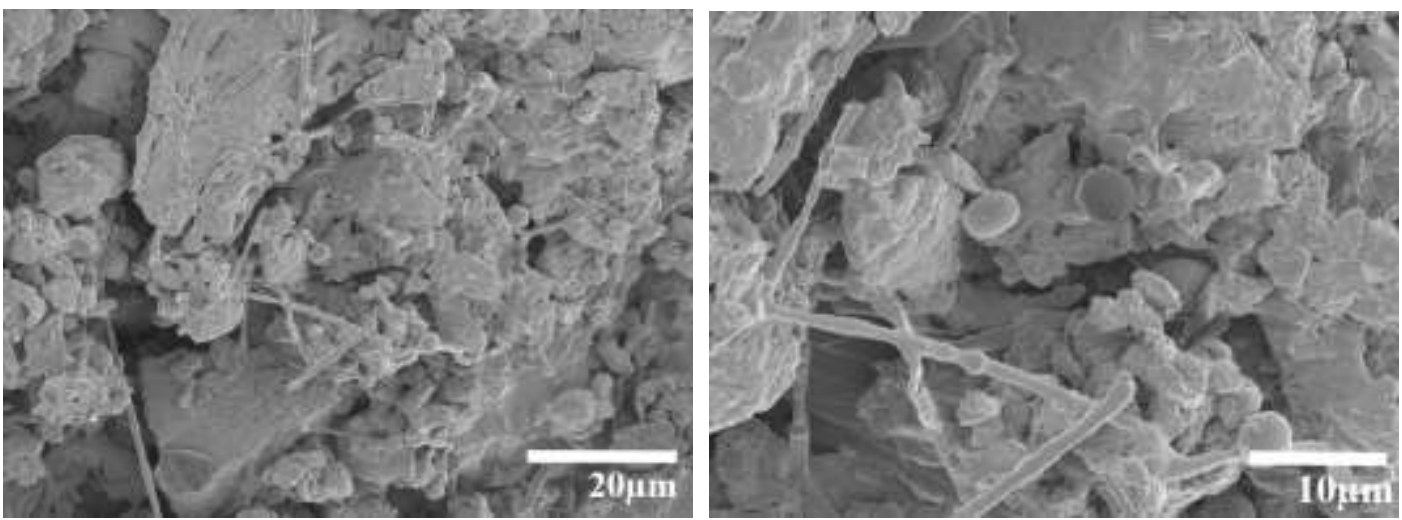

SEM image of bone at magnifications of 1000 and 10,000.
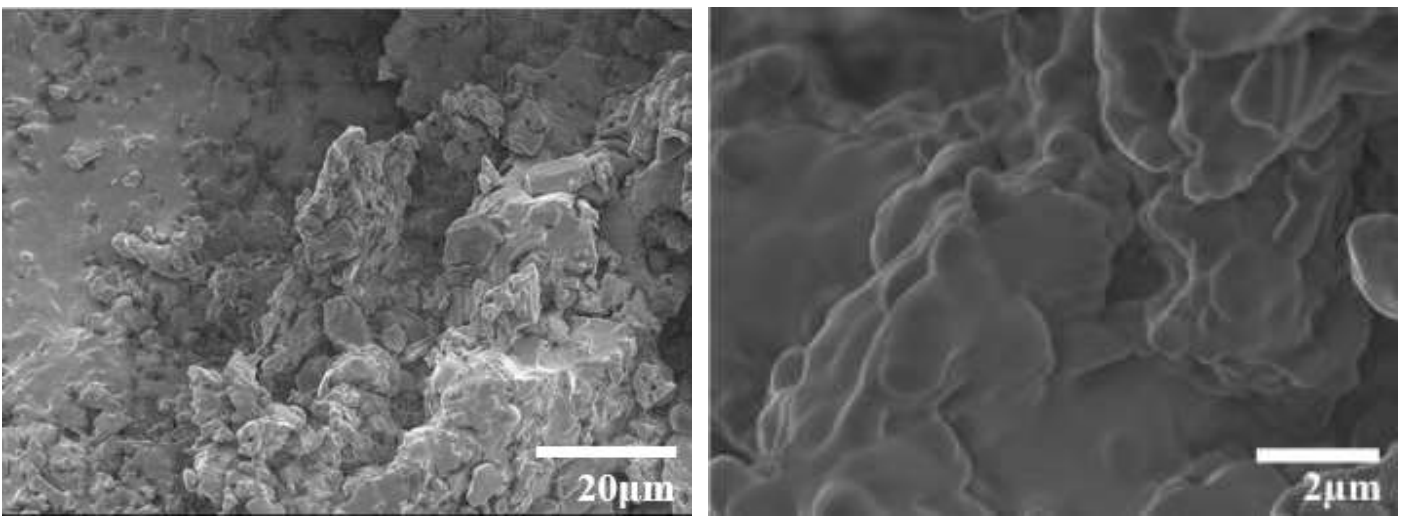

SEM image of meal at magnifications of X1000 and X2500.
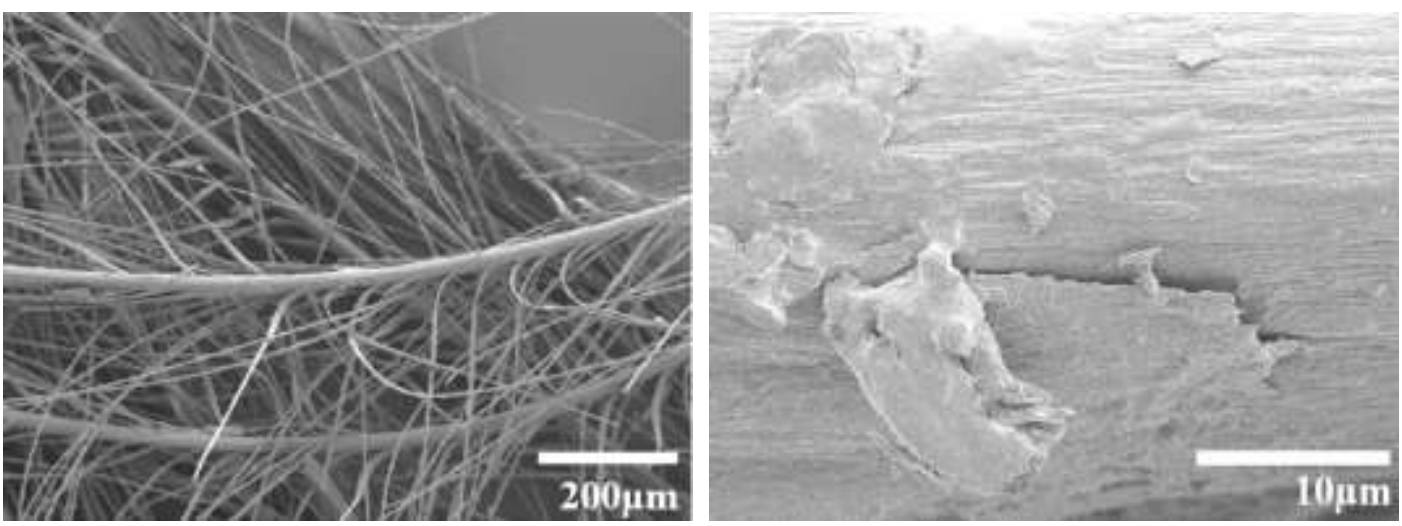

SEM images of feather barbs at magnifications of X100 and X3000. 